\title{
STAKEHOLDER ANALYSIS PADA KEBIJAKAN PEMANFAATAN TELEMEDICINE DALAM MENGHADAPI COVID-19 DI INDONESIA
}

\author{
Andhi Bahtiar ${ }^{1}$, Adis Imam Munandar ${ }^{2}$ \\ Kajian Ketahanan Nasional, Sekolah Kajian Stratejik dan Global, Universitas Indonesia ${ }^{1,2}$ \\ andhi.bahtiar@ui.ac.id ${ }^{1}$, adis.imam@ui.ac.id ${ }^{2}$
}

\begin{abstract}
The use of telemedicine is one of the strategic policies of the Indonesian government to minimize physical contact between doctors and patients in the fight against the Covid-19 pandemic. Various suggestions, directions and decisions from government elements in implementing the policy are aimed at maintaining public health services, without increasing the potential for Covid-19 transmission in health facilities. However, in the midst of optimism for the success of the policy, various policy makers had doubts, especially regarding the readiness of facilities, the ethical dimensions of medical professionalism, and the potential for the emergence of new capitalism in the health sector. Through a qualitative approach based on the stakeholder analysis method, this study maps and identifies the various stakeholders involved in the implementation of telemedicine, as well as their strengths, authorities and interests. The data were obtained through literature studies based on the roles and regulatory bases of each agency, in order to obtain identification of the main tasks and functions of stakeholders related to telemedicine. The results of this study indicate that there are at least thirty-one stakeholders involved, including the Indonesian Ministry of Health, the Covid-19 Task Force and the Indonesian Medical Council as definitive stakeholders, as well as investors, providers of telemedicine platforms and the pharmaceutical industry as dangerous stakeholders. In the successful implementation of telemedicine, it was concluded that definitive stakeholders have great power, authority and interest to determine various telemedicine parameters, such as services, tariffs, supervision and telemedicine business models so that the face of the health world and the government's strategy in suppressing the spread of the Covid-19 outbreak can be successful. through telemedicine services.
\end{abstract}

Keywords : Covid-19, Health Services, Stakeholders Analysis, Telemedicine

\begin{abstract}
ABSTRAK
Pemanfaatan layanan kesehatan jarak jauh (telemedicine) merupakan salah satu kebijakan strategis Pemerintah Indonesia untuk meminimalisir kontak fisik antara dokter dan pasien dalam upaya perang melawan wabah pandemi Covid-19. Berbagai anjuran, arahan dan keputusan unsur pemerintah dalam implementasi kebijakan tersebut ditujukan agar layanan kesehatan masyarakat tetap terjaga, tanpa meningkatkan potensi penularan Covid-19 di lingkungan fasilitas kesehatan. Namun begitu, di tengah optimisme keberhasilan kebijakan tersebut, muncul keraguan dari berbagai pemangku kebijakan, terutama mengenai kesiapan sarana, dimensi etik profesionalisme tenaga medis, serta potensi munculnya kapitalisme baru di dunia kesehatan. Melalui pendekatan kualitatif dengan berbasis metode stakeholder analysis, penelitian ini memetakan dan mengidentifikasi berbagai pemangku kebijakan yang terlibat dalam implementasi telemedicine, sekaligus kekuatan, kewenangan dan kepentingan yang dimilikinya. Data diperoleh melalui studi literatur berdasarkan peran dan dasar regulasi yang dimiliki masing - masing instansi, agar diperoleh identifikasi tugas pokok dan fungsi stakeholder yang berkaitan dengan layanan telemedicine. Hasil penelitian ini menunjukkan setidaknya terdapat tiga puluh satu pemangku kebijakan yang terlibat, diantaranya adalah Kementerian Kesehatan RI, Satuan Tugas Covid19 dan Konsil Kedokteran Indonesia (KKI) sebagai definitive stakeholder, serta investor, penyedia platform telemedicine dan industri farmasi sebagai dangerous stakeholder. Dalam menyukseskan implementasi telemedicine tersebut, disimpulkan bahwa definitive stakeholder mempunyai kekuatan, kewenangan dan kepentingan yang besar untuk menentukan berbagai parameter telemedicine, seperti layanan, tarif, pengawasan serta model bisnis telemedicine agar wajah dunia kesehatan dan strategi pemerintah dalam menekan penyebaran wabah Covid-19 dapat berhasil melalui layanan telemedicine.
\end{abstract}

Kata Kunci : Analisis Stakeholder, Covid-19, Layanan Kesehatan Jarak Jauh 


\section{PENDAHULUAN}

Meluasnya wabah pandemi Covid-19 yang berasal dari Wuhan, China pada akhir 2019 hingga ke seluruh dunia menjadi sebuah bencana global yang sangat mengancam populasi umat manusia (Djoyonegoro, 2020). Penetapan Covid-19 sebagai status darurat global kesehatan masyarakat pada Januari 2020 oleh World Health Organization (WHO) (Santosa, 2020) juga mencerminkan situasi dunia modern di tengah ancaman wabah mematikan tersebut. Menghadapi kondisi tersebut, dunia menerapkan berbagai strategi interupsi seperti deteksi dini, isolasi wilayah serta pelacakan infeksi wabah Covid-19, disamping memastikan pencegahan transmisi dan optimalisasi pengobatan (Sohrabi et al., 2020). Tujuan strategisnya adalah agar penyebaran Covid-19 tidak meluas dan berdampak pada sektor kehidupan manusia lainnya.

Di antara berbagai strategi tersebut, pencegahan penyebaran transmisi menempati prioritas utama dalam penanganan Covid-19. Berbagai negara menerapkan strategi physical distancing, termasuk anjuran tetap di rumah, pembatasan perjalanan serta penutupan fasilitas publik agar interaksi fisik antar manusia dapat dihindari (Gostin and Wiley, 2020). Namun demikian, beberapa layanan publik diyakini menghadapi dilema, termasuk layanan kesehatan yang selama ini lazim menggunakan interaksi fisik antara dokter dan pasien. Fakta bahwa rumah sakit dan tenaga medis mempunyai risiko tinggi terpapar Covid-19 (Ran et al., 2020), menjadikan interaksi antara dokter dan pasien sebagai aktifitas kontak fisik yang harus dijauhi. Di sisi lain, pasien dan pengunjung juga merupakan pembawa pathogen yang potensial (Gan, Lim and Koh, 2020), sehingga penerapan protokol kesehatan serta pembatasan kunjungan juga wajib dilakukan agar tidak ada virus Covid19 yang masuk ke rumah sakit.

Merujuk pada kondisi tersebut, berbagai negara mencoba meningkatkan penggunaan layanan kesehatan jarak jauh atau telemedicine sebagai salah satu strategi dalam menghadapi pandemi Covid-19. Waller and Stotler (2018) meyakini bahwa definisi umum telemedicine tidak jauh berbeda dengan definisi literal gabungan antara kata medicine dan tele, yakni ilmu dan seni pemeliharaan kesehatan, sekaligus pencegahan, pengentasan dan penyembuhan penyakit yang dilakukan secara jarak jauh. Definisi tersebut senada dengan yang disampaikan oleh WHO (2010) bahwa telemedicine atau dalam term lain disebut telehealth adalah pemberian layanan perawatan kesehatan secara jarak jauh oleh semua tenaga profesional kesehatan dengan bantuan peralatan informasi dan teknologi komunikasi dalam pertukaran informasi, pengobatan, pencegahan penyakit dan cedera, penelitian dan evaluasi, serta pendidikan penyedia layanan kesehatan. Lebih lanjut, Grigsby and Sanders (1998) menyebutkan bahwa program tersebut ditemukan pertama kali sekitar tahun 1960an, meskipun baru berkembang pesat pasca 1990-an, yang oleh Craig and Patterson (2005) disebut sebagai jawaban dari tantangan umat manusia pada Abad 21 dalam menghadapi ketersediaan perawatan kesehatan berkualitas bagi semua pihak. Seiring dengan perkembangan teknologi modern, telemedicine yang pada mulanya berkembang dalam komunikasi satelit antar wilayah, kini bertransformasi menjadi layanan kesehatan berbasis aplikasi digital (Wiweko, Zesario and Agung, 2016).

Sementara itu, kajian mengenai perkembangan telemedicine banyak ditemukan di berbagai literatur, terutama yang membahas mengenai konsep, manfaat, serta polemiknya pada aspek etika profesionalitas dan legalitas hukum. Namun mayoritas peneliti sepakat bahwa telemedicine merupakan kunci layanan kesehatan di masa depan. Pacis, Subido and Bugtai (2018) bahkan menyebutkan bahwa tren telemedicine akan terus berkembang, terutama beriringan dengan perkembangan artificial intelligence (AI), sehingga penggunaan telemedicine akan sampai pada 
pemantauan pasien, informasi perawatan kesehatan, bantuan diagnosa, serta kolaborasi analisis informasi.

Manfaat serta praktik penggunaan telemedicine di berbagai negara dalam menghadapi Covid-19 juga banyak dikaji, seperti Calton, Abedini and Fratkin (2020) yang meneliti penggunaan telemedicine di Amerika Serikat, Mahajan, Singh and Azad (2020) di India, Omboni (2020) di Italia, serta Pinzon, Paramitha and Wijaya (2020) di Indonesia. Beragam implementasi telemedicine di masa Covid-19 juga banyak diteliti seperti Bhaskar et al. (2020) yang mengusulkan penggunaan artificial intelligence dan robotics dalam penanganan pasien Covid-19, Bokolo Anthony Jnr (2020) dalam remote treatment, serta Royce, Sanoff and Rewari (2020) yang meneliti pemanfaatan telemedicine dalam menangani pasien kanker. Kesimpulan diutarakan oleh Hollander and Carr (2020) yang meneliti praktek telemedicine di USA, bahwa meskipun telemedicine bukan jawaban sempurna bagi Covid-19, namun keberadannya merupakan solusi bagi kebutuhan pasien, baik bagi pasien Covid-19 maupun pasien non-Covid-19 dalam menerima layanan kesehatan.

Sementara itu, meskipun praktik telemedicine di Indonesia sudah ada sebelumnya, penekanan peningkatan implementasi telemedicine setidaknya tertuang dalam Peraturan Konsil Kedokteran Indonesia (KKI) Nomor 74 Tahun 2020 tentang Kewenangan Klinis Dan Praktik Kedokteran Melalui Telemedicine pada Masa Pandemi Corona Virus Disease 2019 (Covid-19) di Indonesia (Konsil Kedokteran Indonesia, 2020). Peraturan tersebut bertujuan untuk memberikan kewenangan klinis tambahan serta kepastian hukum bagi dokter dan dokter gigi dalam melakukan layanan telemedicine yang selama ini belum jelas. Langkah tersebut juga sejalan dengan rekomendasi WHO untuk mengintensifkan penggunaan telemedicine sebagai salah satu upaya dalam meminimalkan penggunaan Alat Pelindung Diri (APD) bagi tenaga medis.
Namun begitu, di tengah langkah positif tersebut, berbagai keraguan mengenai implementasi telemedicine juga bermunculan, salah satunya mengenai dimensi etik profesionalitas kedokteran. Praktik telemedicine bahkan dianggap tidak mengakomodir perilaku profesional dokter yang diharuskan memeriksa pasien terlebih dahulu, sebelum memberikan terapi atas diagnosa yang telah diambil (Kuntardjo, 2020). Selain itu, di tengah banyaknya kasus malapraktik, telemedicine juga dapat meningkatkan risiko kelalaian dokter dalam mendiagnosa pasien, karena tidak disertai tatap muka seperti layanan pada umumnya (Dharma, 2020).

Di sisi lain, aspek keuntungan ekonomi pada layanan telemedicine juga tidak dapat dikesampingkan. Laporan Google dan Temasek (2020) dalam e-economy SEA 2020 bahkan menyebut bahwa pengguna telemedicine di Asia Tenggara telah meningkat sebanyak empat kali lipat selama pandemi Covid-19 serta mengalami peningkatan investasi dari 19 juta USD menjadi 22 juta USD selama semester pertama tahun 2020. Merujuk pada pernyataan Jian (2020) yang menyebut bahwa lembaga pelayanan kesehatan berorientasi pada profit, maka implementasi keberhasilan telemedicine di Indonesia juga harus mempertimbangkan aspek keekonomian, yang pada dimensi lainnya rawan dijadikan sebagai komoditas kapitalisme baru di dunia kesehatan.

Banyaknya pemangku kebijakan yang terlibat dalam implementasi telemedicine membuat penilaian kebijakan tersebut harus dianalisa dari berbagai sudut pandang. Oleh karena itu, penelitian ini akan menekankan pada pengkajian kebijakan melalui metode stakeholder analisis yang belum pernah ditemukan pada penelitian sebelumnya. Melalui metode tersebut, penelitian ini akan memetakan berbagai pihak yang terlibat dalam upaya implementasi telemedicine di Indonesia, sehingga dapat menggambarkan secara utuh kekuatan (power), kepentingan (urgency) serta kewenangan (legitimacy) yang dimiliki oleh masing - masing 
stakeholder. Tujuan analisis tersebut dibutuhkan dalam rangka mengidentifikasi dan memahami hubungan yang dimiliki antar stakeholder dalam layanan telemedicine, sehingga pemangku kebijakan utama dapat mengembangkan tindakan yang sesuai bagi tindak lanjut implementasi telemedicine di Indonesia.

\section{METODE}

Adanya pergeseran paradigma dari pemerintah (government) menjadi pemerintahan (governance) membuat pemerintah tidak lagi menjadi aktor tunggal sebagai penentu kebijakan. Hal tersebut sesuai yang disampaikan oleh Usman (2016) yang mengatakan bahwa dalam perspektif governance, kebijakan publik dirumuskan oleh tiga pihak, yaitu pemerintah, masyarakat, dan pihak swasta. Utoyo (2017) juga menyebutkan bahwa terminologi governance mengakui adanya banyak pusat pengambilan keputusan yang bekerja pada tingkat berbeda, sehingga seluruh pihak terkait dianggap sebagai bagian dari proses pengambilan kebijakan. Keterlibatan dan interaksi banyak pihak atau yang disebut stakeholder tersebut juga memberi kontribusi dalam menghasilkan kebijakan yang secara rasionalitas lebih baik (Apriansyah and Munandar, 2019).

Dalam menganalisa pengaruh banyak pihak dalam sebuah kebijakan, Freeman (2015) mengenalkan metode pendekatan stakeholder analysis yang pada intinya berguna untuk menganalisa hubungan antar pihak, baik yang dipengaruhi maupun yang mempengaruhi sebuah kebijakan. Melanjutkan teori tersebut, Mitchell, Agle and Wood (1997) mengklasifikasikan stakeholder sesuai tiga atribut utama, yaitu berdasarkan kekuatan (power), kewenangan (legitimacy) dan kepentingannya (urgency) dalam sebuah kebijakan (Gambar 1).

Secara singkat, kombinasi stakeholder Teori Mitchell terbagi menjadi delapan kombinasi, yaitu (1) Dormant stakeholders, atau pemangku kebijakan yang mempunyai power, namun karena tidak memiliki legitimacy dan urgency, maka perannya menjadi pasif; (2) Discretionary stakeholders, yaitu pemangku kebijakan yang memiliki atribut legitimacy namun tidak memiliki kekuatan dan kepentingan yang mendesak, sehingga perannya hanya sebagai penerima tanggung jawab; (3) Demanding stakeholders atau pemangku kebijakan yang menuntut atau mendesak sebuah kebijakan karena atribut urgency yang besar; (4) Dominant stakeholders, biasanya dicirikan sebagai pemangku kebijakan yang mempunyai power dan legitimacy, sehingga perannya sangat vital dalam sebuah kebijakan; (5) Dangerous stakeholders, atau pemangku kebijakan yang mempunyai kekuatan dan kepentingan, sehingga perannya dapat berpotensi koersif dan berbahaya karena bersifat memaksa; (6) Dependent stakeholders atau pemangku kebijakan yang bergantung pada pihak lain yang lebih mempunyai power atas kebijakan; (7) Definitive Stakeholders, yakni pemangku kebijakan yang memiliki ketiga atribut utama; serta (8) Nonstakeholder yakni pihak yang tidak mempunyai ketiga atribut utama dalam sebuah kebijakan.

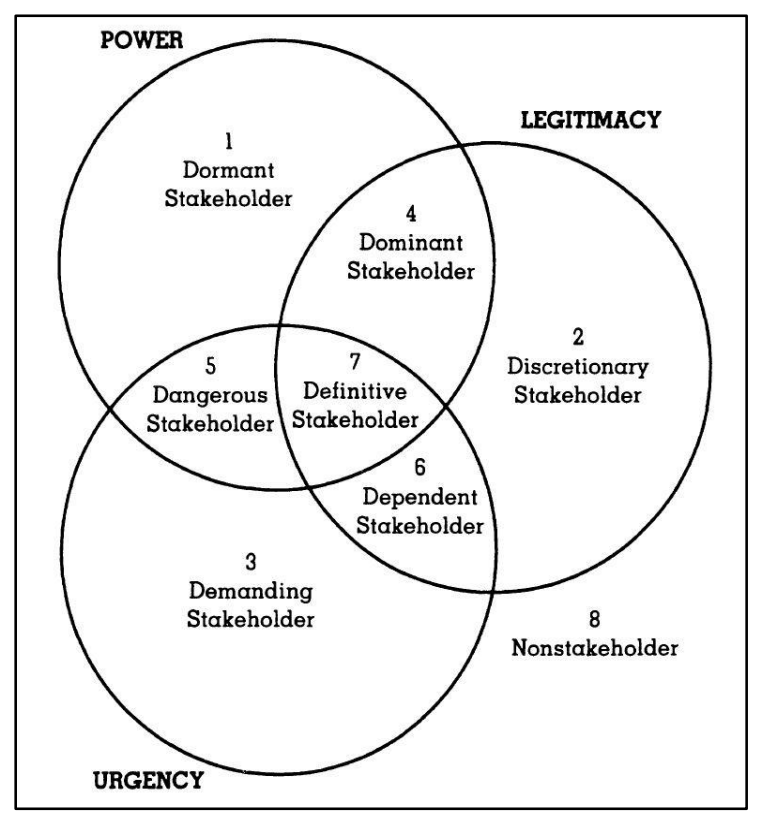

Gambar 1. Kombinasi atribut Teori Mitchell

Berbasis teori tersebut, penelitian ini akan menggunakan pendekatan kualitatif dengan metode deskriptif analisis terhadap 
delapan kombinasi stakeholder dalam Teori Mitchell. Melalui pendekatan tersebut, data berupa aktor - aktor yang mempunyai kaitan dengan layanan telemedicine di Indonesia akan disusun dan dipetakan berdasarkan peran, tugas pokok dan fungsi sesuai dasar regulasi yang dimiliki. Regulasi diperoleh melalui data sekunder berupa studi pustaka dari berbagai sumber terbuka seperti portal website DPR RI, Kemenkumham dan portal resmi lembaga yang sedang diteliti. Bersumber data tersebut, informasi berupa kekuatan, kewenangan dan kepentingan masing - masing stakeholder diambil, dianalisa, diverifikasi dan selanjutnya diidentifikasi ke dalam unsur - unsur kombinasi stakeholder dalam Teori Mitchell.

\section{HASIL}

Melalui studi literatur yang dilakukan terhadap portal Jaringan Dokumentasi dan Informasi Hukum (JDIH) DPR RI, portal Kementerian / Lembaga (K/L) terkait, serta berbagai sumber terbuka lainnya, diperoleh setidaknya 31 stakeholder yang mempunyai keterlibatan terhadap implementasi telemedicine di Indonesia. Dalam rangka memudahkan identifikasi dan peran masing - masing stakeholder tersebut, perlu dirumuskan lima kategori stakeholder sebagai berikut: lembaga negara, organisasi profesi kesehatan, organisasi kemasyarakatan, sektor swasta dan bisnis serta aktor luar negeri. Secara detail, stakeholder beserta peran dan dasar regulasinya dijelaskan dalam tabel 1 .

Tabel 1. Stakeholder Mapping Implementasi Telemedicine

\begin{tabular}{|c|c|c|}
\hline No & Lembaga/ Aktor & Peran dan Dasar Regulasi \\
\hline \multicolumn{3}{|c|}{ Kategori : Lembaga Negara } \\
\hline 1 & Presiden RI & $\begin{array}{l}\text { Pemegang kekuasaan pemerintahan (UUD } 1945 \text { Pasal } 4 \text { ayat 1), pengajuan } \\
\text { RUU (Pasal } 5 \text { ayat } 1 \text { ) }\end{array}$ \\
\hline 2 & $\begin{array}{l}\text { Dewan Perwakilan Rakyat } \\
\text { (DPR) }\end{array}$ & Fungsi legislasi, anggaran dan pengawasan (UUD 1945 Pasal 20a ayat 1) \\
\hline 3 & Kominfo & $\begin{array}{l}\text { Perumusan dan pelaksana teknis layanan komunikasi dan informatika } \\
\text { nasional (Perpres 54/2015) }\end{array}$ \\
\hline 4 & Kemenkes & Pelaksana kebijakan kesehatan dan pengendalian penyakit (Perpres 35/2015) \\
\hline 5 & $\begin{array}{l}\text { Satgas Penanganan Covid- } \\
19\end{array}$ & $\begin{array}{l}\text { Mencegah, merespon dan mempercepat penanganan Covid-19 (Perpres } \\
\text { 7/2020; Perpres 82/2020) }\end{array}$ \\
\hline 6 & Kemendagri & Pencatatan sipil, pengembangan masyarakat dan daerah (UUD 1945) \\
\hline 7 & $\begin{array}{l}\text { Dewan TIK Nasional } \\
\text { (Wantiknas) }\end{array}$ & $\begin{array}{l}\text { Merumuskan, membuat dan sinkronisasi kebijakan TIK antara K/L dan } \\
\text { stakeholder nasional (Keppres 1/2014) }\end{array}$ \\
\hline 8 & Kemenkumham & $\begin{array}{l}\text { Perumusan dan harmonisasi peraturan perundang-undangan (Perpres } \\
44 / 2015 \text { ) }\end{array}$ \\
\hline 9 & Bappenas & $\begin{array}{l}\text { Merencanakan kebijakan dan pembangunan nasional, termasuk sarana } \\
\text { prasarana kesehatan. (Perpres } 65,66 / 2015 \text { ) }\end{array}$ \\
\hline 10 & Kemenristekdikti & $\begin{array}{l}\text { Perumusan, pengembangan serta penetapan inovasi dan teknologi kesehatan } \\
\text { (Perpres 13/2015) }\end{array}$ \\
\hline 11 & $\begin{array}{l}\text { Kemendesa, PDT dan } \\
\text { Transmigrasi }\end{array}$ & $\begin{array}{l}\text { Perumusan, pembinaan, pengembangan dan penelitian masyarakat pedesaan } \\
\& \text { PDT (Perpres 12/2015) }\end{array}$ \\
\hline 12 & LAPAN & Pengkajian sarana telemedicine berbasis satelit (Perpres 49/2015) \\
\hline 13 & BPJS & Jaminan kesehatan nasional (UU 24/2011) \\
\hline 14 & BSSN & Pengamanan siber nasional dan transaksi elektronik (Perpres 53,133/2017) \\
\hline 15 & BPS & $\begin{array}{l}\text { Penyusunan dan kajian statistik kondisi kesehatan masyarakat (Perpres } \\
\text { 86/2007) }\end{array}$ \\
\hline
\end{tabular}

Kategori : Unit dan Organisasi Kesehatan 


\begin{tabular}{|c|c|c|}
\hline 16 & Rumah sakit dan klinik & $\begin{array}{l}\text { Kewajiban pemberian layanan dan penyediaan sarana - prasarana kesehatan } \\
\text { (Permenkes 4/2018) }\end{array}$ \\
\hline 17 & Organisasi profesi medis & $\begin{array}{l}\text { Menjalankan praktik pelayanan kesehatan dan mendapatkan hak } \\
\text { perlindungan keselamatan (UU 36/2014) }\end{array}$ \\
\hline 18 & Laboratorium Kesehatan & $\begin{array}{l}\text { Membantu program pemerintah di bidang layanan kesehatan pada } \\
\text { masyarakat (Permenkes 411/2010) }\end{array}$ \\
\hline 19 & $\begin{array}{l}\text { Konsil Kedokteran } \\
\text { Indonesia (KKI) }\end{array}$ & $\begin{array}{l}\text { Pembinaan praktik kedokteran dan peningkatan mutu layanan kesehatan (UU } \\
\text { 29/2004) }\end{array}$ \\
\hline \multicolumn{3}{|c|}{ Kategori : Kemasyarakatan } \\
\hline 20 & $\begin{array}{l}\text { Lembaga akademik } \\
\text { (perguruan tinggi) }\end{array}$ & $\begin{array}{l}\text { Inovasi dan riset teknologi kesehatan nasional }(\mathrm{PP} \text { 04/2014; } \\
\text { Permenristekdikti 23, 39/2018) }\end{array}$ \\
\hline 21 & Forum Pasien & Konsumen layanan telemedicine \\
\hline 22 & $\begin{array}{l}\text { Yayasan Lembaga } \\
\text { Konsumen Indonesia } \\
\text { (YLKI) }\end{array}$ & $\begin{array}{l}\text { Kepedulian hak dan kewajiban pasien dalam layanan telemedicine (UU } \\
\text { 8/1999) }\end{array}$ \\
\hline \multicolumn{3}{|c|}{ Kategori : Sektor Swasta dan Bisnis } \\
\hline 23 & $\begin{array}{l}\text { Penyedia Platform } \\
\text { Telemedicine }\end{array}$ & Penyedia aplikasi telemedicine swasta (profit oriented) (Permenkes 46/2017) \\
\hline 24 & Investor & Pendanaan sektor swasta, dari dalam dan luar negeri (Permenkes 46/2017) \\
\hline 25 & Industri farmasi & Perumusan standar layanan telemedicine (Permenkes 46/2017) \\
\hline 26 & Operator Internet (ISP) & $\begin{array}{l}\text { Penyedia infratruktur fisik dan internet untuk layanan telemedicine } \\
\text { (Permenkes 46/2017) }\end{array}$ \\
\hline 27 & Asuransi kesehatan & Badan penjamin pasien untuk layanan telemedicine (UU 40/2014) \\
\hline 28 & Apotik & $\begin{array}{l}\text { Penyedia obat dan pendukung layanan kesehatan (PP 26/1965; Kepmenkes } \\
1332 / 2002 \text { ) }\end{array}$ \\
\hline \multicolumn{3}{|c|}{ Kategori : Aktor / organisasi LN } \\
\hline 29 & $\begin{array}{l}\text { World Health Organisation } \\
\text { (WHO) }\end{array}$ & $\begin{array}{l}\text { Koordinator kesehatan publik internasional, penanggungjawab penanganan } \\
\text { Covid-19 internasional }\end{array}$ \\
\hline 30 & Lembaga penelitian LN & $\begin{array}{l}\text { Join research dengan lembaga penelitian dalam negeri untuk implementasi } \\
\text { telemedicine }\end{array}$ \\
\hline 31 & Foreign Government & Kerjasama $G$-to-G terkait layanan telemedicine internasional. \\
\hline
\end{tabular}

\section{PEMBAHASAN}

\section{Stakeholder Mapping}

Berdasarkan pemetaan pemangku kebijakan pada tabel 1, semua aktor yang terlibat dalam implementasi telemedicine dianalisa berdasarkan perannya masing masing. Pada kategori lembaga negara, peran presiden dan Dewan Perwakilan Rakyat (DPR) menempati porsi utama dalam merealisasikan kemauan politik negara (political will state) dalam menginisiasi serta merealisasikan kebijakan telemedicine dengan berbagai variannya. Beyrer et al. (2015) menyebut bahwa kemauan politik adalah sebuah intervensi kesehatan publik paling efektif dalam sejarah, yang oleh Stein (2015) disebut sangat mempengaruhi kelayakan layanan medis dalam mencegah, mengendalikan dan memberantas wabah penyakit menular. Oleh karena itu, arahan dan perintah presiden serta dukungan legislatif pada Kementerian / Lembaga $(\mathrm{K} / \mathrm{L})$ negara yang terkait dalam penanganan Covid-19 akan sangat berpengaruh terhadap percepatan dan efektifitas telemedicine dalam melawan wabah pandemi tersebut.

Selanjutnya, di antara K/L yang mempunyai peran signifikan adalah Kementerian Kesehatan (Kemenkes) yang menyelenggarakan fungsi perumusan dan pelaksanaan kebijakan di bidang kesehatan masyarakat, serta pencegahan dan pengendalian penyakit (Sianipar, 2015). Dalam melaksanakan fungsi tersebut, implementasi telemedicine sebagai salah satu strategi pencegahan penyebaran Covid19 menjadi domain utama Kemenkes, 
termasuk standart operation procedure $(S O P)$, regulasi serta pelatihan profesional bagi tenaga medis yang terlibat. Peran nyata keterlibatan Kemenkes tersebut setidaknya terdapat pada inovasi aplikasi konsultasi kesehatan daring gratis yang diberi nama SehatPedia serta berbagai kerjasama dengan negara lain seperti Inggris dalam akselerasi penggunaan telemedicine berbasis komunitas (Kemenkes RI, 2020).

Selanjutnya, peran Satuan Tugas (Satgas) Covid-19 sebagai garda terdepan dalam penanganan Covid-19 juga sangat besar, karena berkepentingan dalam penggunaan berbagai strategi nasional melawan penyebaran wabah mematikan tersebut. Selain Kemenkes dan Satgas Covid-19, perencanaan telemedicine secara nasional juga harus melibatkan Kementerian Perencanaan Pembangunan Nasional/Badan Perencanaan Pembangunan Nasional (PPN/Bappenas), Kementerian Dalam Negeri (Kemendagri), Kementerian Desa, PDT dan Transmigrasi, dan Biro Pusat Statistik (BPS). Lembaga - lembaga tersebut diperlukan perannya untuk mengidentifikasi kondisi penduduk Indonesia, terutama yang berkaitan dengan akses teknologi internet, kemiskinan, dan kondisi layanan kesehatan di berbagai daerah. Informasi tersebut penting karena implementasi telemedicine merupakan program nasional yang tidak hanya akan digunakan menghadapi Covid19, namun juga sebagai backbone layanan kesehatan di masa depan (Bashshur et al., 2020).

Di sisi lain, peran Kementerian Komunikasi dan Informasi (Kominfo) dalam penyediaan jaringan internet dan Lembaga Penerbangan dan Antariksa Nasional (LAPAN) dalam penyediaan jaringan satelit juga sangat signifikan dalam implementasi satelit. Kemampuan dan kewenangan kedua lembaga tersebut dalam penyediaan akses telemedicine diperlukan agar layanan telemedicine dapat dijangkau oleh semua wilayah di Indonesia. Selain itu, dalam rangka menjamin kerahasiaan data pasien dan komunikasi digital sesuai UU Nomor 36 tahun 2009 tentang Kesehatan, maka diperlukan peran dari Badan Siber dan Sandi Negara (BSSN) yang mempunyai tugas pokok dalam penyusunan regulasi dan pengamanan siber nasional.

Sementara itu, pada kategori organisasi kesehatan, rumah sakit, klinik dan laboratorium kesehatan juga menjadi penentu implementasi telemedicine di Indonesia, baik secara mandiri maupun yang tergabung dalam perhimpunan rumah sakit, seperti Perhimpunan Rumah Sakit Seluruh Indonesia (PERSI) dan Asosiasi Rumah Sakit Swasta Indonesia (ARSSI). Peran tersebut terutama terlihat dalam kesiapan, kemauan dan keseriusan rumah sakit dalam penerapan telemedicine sebagai salah satu strategi menghadapi pandemi Covid-19. Bragazzi et al. (2020) bahkan menyebut bahwa rumah sakit dan komunitas farmasi harus berperan aktif dalam memonitor, konsultasi dan konseling psikologis pada pasien Covid-19 secara jarak jauh. Di samping fasilitas kesehatan, peran profesi petugas medis juga sangat signifikan dalam mendorong dan mengusulkan metode implementasi telemedicine yang baik. PB Ikatan Dokter Indonesia (IDI) misalnya, dengan menerbitkan Pedoman Standar Perlindungan Dokter Era Covid-19 pada September 2020, telah ikut merekomendasikan penggunaan telemedicine pada pasien, sekaligus anjuran pada dokter untuk menyebarluaskan informasi dan fasilitas telemedicine kepada masyarakat (PB IDI, 2020). Keputusan Konsil Kedokteran Indonesia (KKI) sebagai badan independen yang bertanggung jawab langsung kepada Presiden RI juga menguatkan klaim bahwa dokter dan tenaga kesehatan lainnya harus menjadi fokus kajian implementasi telemedicine di Indonesia.

Selanjutnya pada kategori kemasyarakatan, peran masyarakat sosial sebagai pasien sekaligus konsumen layanan telemedicine juga menempati nilai strategis. da Luz (2019) menyebut bahwa hubungan dokter - pasien pada telemedicine harus didasari oleh kepercayaan, baik terhadap dokter maupun pada layanan yang diberikan, 
sehingga orientasi kebutuhan pasien harus didahulukan, terutama kerahasiaan data. Untuk menjamin hal tersebut, juga terdapat peran Yayasan Lembaga Konsumen Indonesia (YLKI) yang dapat memberikan perlindungan bagi pasien dan konsumen telemedicine. Selain itu, lembaga pendidikan seperti perguruan tinggi dan rumah sakit pendidikan juga mempunyai peran penting dalam riset serta pengembangan telemedicine, dikaitkan dengan berbagai perkembangan dinamis yang mengiringi pandemi Covid-19.

Pada kategori unit bisnis dan sektor swasta, peran penyedia platform layanan kesehatan bertindak sebagai aktor signifikan dalam implementasi telemedicine $\mathrm{di}$ Indonesia, selain investor, asuransi dan produsen peralatan kesehatan. Layanan telemedicine saat ini bahkan diyakini telah didominasi oleh perusahaan yang berorientasi profit, sehingga pertumbuhannya selalu diiringi dengan peningkatan pendanaan dari venture capital dan masifnya penawaran rencana kesehatan (asuransi) (Elliott and Yopes, 2019). Selain aktor - aktor tersebut, terdapat juga peran operator internet dan apotik sebagai bagian dari kelompok bisnis dan sektor swasta yang juga dapat dianggap sebagai stakeholder implementasi telemedicine.

Sementara itu, pada kategori luar negeri, peran World Health Organisation (WHO) sebagai koordinator kesehatan umum internasional di bawah United Nations (UN) juga sangat signfikan dalam menentukan standar telemedicine yang baik. Selain itu, berbagai kerjasama Indonesia melalui model Government-to-Government (G-to-G) maupun penelitian akademik internasional juga membuktikan bahwa terdapat unsur stakeholder luar negeri yang juga berpengaruh terhadap implementasi telemedicine di Indonesia.

\section{Identifikasi Stakeholder}

Dalam rangka mendalami peran masing - masing stakeholder, diperlukan identifikasi lanjutan mengenai kekuatan (power), kepentingan (urgency) dan kewenangan (legitimacy) yang dimiliki. Identifikasi stakeholder tersebut difokuskan pada peran stakeholder dalam merumuskan ketentuan serta penekanan implementasi telemedicine sebagai salah satu strategi dalam penanganan Covid-19 di Indonesia. Merujuk pada delapan kombinasi stakeholder dalam Teori Mitchell, berikut akan disampaikan mengenai identifikasi 31 stakeholder, dengan penomoran merujuk pada Tabel 1.

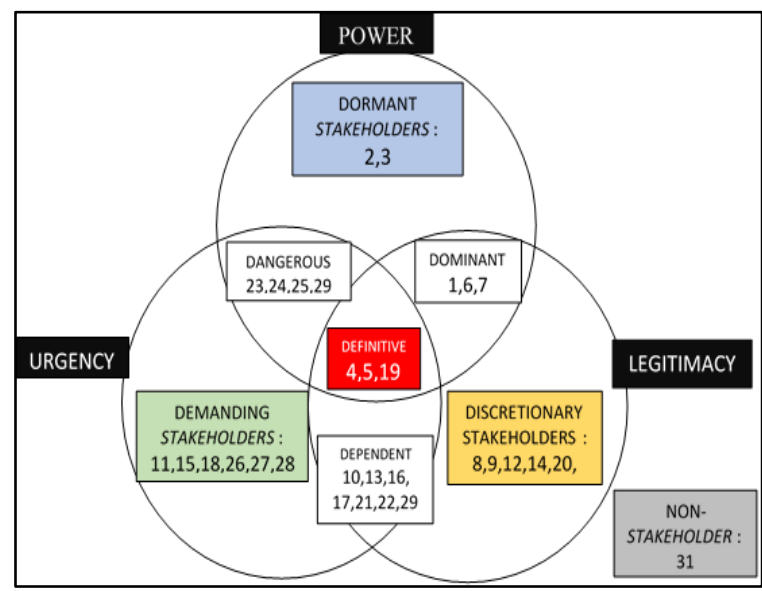

Gambar 2. Identifikasi Stakeholder

Pada kategori dormant stakeholder, terdapat dua pemangku kebijakan yakni DPR RI dan Kominfo sebagai pemilik kekuatan (power) untuk merumuskan kebijakan layanan telemedicine berbasis TIK. Namun karena tidak memiliki kewenangan (legitimacy) dan kepentingan (urgency) langsung dalam penanganan Covid-19, kedua stakeholder tersebut bersifat pasif menunggu instruksi. Sedangkan pada kategori discretionary stakeholders, terdapat beberapa pemangku kebijakan seperti Kemenkumham, Bappenas, LAPAN, BSSN, Perguruan Tinggi (PT) dan lembaga penelitian dari luar negeri. Para aktor tersebut mempunyai atribut tunggal yakni kewenangan untuk merencanakan dan memberi masukan dalam implementasi telemedicine. Tanpa kekuatan dan kepentingan yang mendesak, peran pemangku kebijakan dalam discretionary stakeholders juga bersifat pasif, hanya menerima tanggung jawab yang diberikan 
kepadanya. Sementara pada pemilik atribut tunggal lainnya, yakni pemangku kebijakan yang mempunyai kepentingan (demanding stakeholder) terhadap implementasi telemedicine, terdapat beberapa pemangku kebijakan seperti Kemendesa, PDT dan Transmigrasi, BPS, laboratorium kesehatan, operator internet, asuransi kesehatan dan apotik. Para stakeholder tersebut diyakini memiliki kepentingan, baik yang bersifat profit maupun non-profit seperti kesejahteraan dan kesehatan masyarakat.

Selanjutnya pada kombinasi antara dua atribut, pemangku kebijakan seperti Presiden RI, Kemendagri dan Wantiknas dapat dikategorikan sebagai dominant stakeholders, karena mempunyai power dan legitimacy yang tinggi. Peran ketiganya dalam perencanaan dan strategi penerapan telemedicine di seluruh wilayah Indonesia sangat vital, sehingga keberhasilan implementasinya juga tergantung pada political will dari pemangku kebijakan tersebut. Sedangkan pada dangerous stakeholders, beberapa aktor seperti penyedia platform, investor, dan industri farmasi dianggap mempunyai kepentingan sekaligus kekuatan berupa dana yang besar. Dengan memiliki dua atribut tersebut, ketiga stakeholder dianggap berbahaya karena dapat mempunyai peran memaksa, baik pada saat perencanaan maupun saat implementasi telemedicine. Berbagai kepentingan profit dapat menjadi kontra-produktif terhadap penanganan Covid-19, sehingga regulasi dan Standar Operational Procedure harus menjadi pedoman bagi implementasi telemedicine di Indonesia.

Sementara pada dependent stakeholders, yakni pemangku kebijakan yang mempunyai kewenangan dan kepentingan, ditemukan sejumlah aktor seperti World Health Organisation (WHO), Kemenristekdikti, BPJS, fasilitas pelayanan kesehatan (fasyankes), organisasi profesi medis, serta forum pasien dan YLKI. Aktor - aktor tersebut mempunyai kepentingan dan kewenangan dalam ikut menyukseskan implementasi telemedicine. Rumah sakit dan dokter misalnya, harus ikut serta dalam perumusan kebijakan karena terlibat langsung dalam pemberian layanan telemedicine. Di sisi lain, pasien dan YLKI juga mempunyai kepentingan dan kewenangan dalam menerima layanan kesehatan yang baik, tanpa adanya risiko kebocoran data pribadi maupun potensi malapraktik dokter karena dilakukan secara jarak jauh.

Selanjutnya, di antara beberapa stakeholder tersebut, terdapat tiga aktor yang dapat diidentifikasi memenuhi unsur sebagai definitive stakeholder, yakni Kemenkes, Satgas Penanganan Covid-19 dan Konsil Kedokteran Indonesia (KKI). Ketiganya dianggap memiliki tiga atribut utama dalam implementasi telemedicine, yaitu kekuatan, kewenangan dan kepentingan. Kemenkes misalnya, melalui dasar hukum Perpres No 35 Tahun 2015 Kementerian Kesehatan telah diberi kekuatan sebagai penyelenggara urusan pemerintahan bidang kesehatan (Pasal 2) dan mempunyai wewenang dalam pelaksanaan kebijakan, termasuk pelayanan kesehatan, serta pencegahan dan pengendalian penyakit (Pasal 3). Sedangkan pada penanganan Covid-19, Kemenkes juga mempunyai kepentingan yang mendesak agar wabah pandemi mematikan tersebut dapat segera dikendalikan. Dengan berbagai atribut tersebut, Kemenkes menjadi salah satu pemangku kebijakan yang definitif dalam merumuskan kebijakan telemedicine di Indonesia. Atribut yang sama juga dimiliki KKI sebagai badan otonom yang dibentuk untuk melindungi masyarakat dan meningkatkan mutu layanan kesehatan. Melalui kekuatan yang diberikan oleh UU Nomor 29 Tahun 2004 tentang Praktik Kedokteran, KKI juga terbukti memiliki wewenang dalam mengeluarkan Peraturan KKI Nomor 74 Tahun 2020 tentang praktik kedokteran melalui telemedicine di masa pandemi Covid-19. Melalui peraturan tersebut, KKI dianggap telah memberikan kepastian hukum bagi tenaga kesehatan dalam memberikan pelayanan kesehatan jarak jauh (PORI, 2020). 
Sementara itu, pemerintah negara lain dianggap sebagai non-stakeholder karena tidak berkaitan langsung dengan kebijakan implementasi telemedicine di Indonesia, namun hanya berperan sebagai konsultan ataupun mitra edukasi.

\section{KESIMPULAN}

Penelitian ini menunjukkan bahwa pemerintah dengan segala unsurnya tidak menjadi aktor tunggal penentu kebijakan telemedicine di Indonesia. Setidaknya ditemukan 31 aktor yang mempunyai porsi terhadap kekuatan, kewenangan dan kepentingan terhadap kebijakan tersebut. Banyaknya aktor yang terlibat, membuat tiga aktor utama yang berada dalam kategori devinitive stakeholder, yakni Kemenkes RI, Satgas Penanganan Covid-19 dan Konsil Kedokteran Indonesia (KKI) menjadi penentu utama kebijakan telemedicine, baik dalam menekan penyebaran Covid-19 maupun merubah wajah layanan kesehatan nasional, Perannya dalam merumuskan, melaksanakan dan mengatur implementasi telemedicine, termasuk pelatihan dan pengawasannya, menjadi sangat vital bagi keberhasilan layanan tersebut di masa depan. Regulasi yang komprehensif dalam menjembatani hubungan antar stakeholder yang terlibat juga dibutuhkan agar peran, kewenangan dan tindakannya tidak saling tumpang tindih serta berpotensi kontraproduktif terhadap tujuan yang ingin dicapai dari implementasi telemedicine.

\section{UCAPAN TERIMAKASIH}

Terima kasih yang tulus kami sampaikan kepada para tenaga kesehatan di seluruh Indonesia, atas pengabdian dan pengorbanannya dalam memerangi Covid19. Semoga telemedicine menjadi salah satu kunci kemenangan kita menghadapi virus tersebut, sekaligus memajukan dunia kesehatan Indonesia di masa depan.

\section{DAFTAR PUSTAKA}

Apriansyah, T. and Munandar, A. I. (2019)
'Post Border Control Policy: Stakeholder Analysis Perspective', Customs Research and Applications Journal, 1(1), pp. 111-125.

Bashshur, R. et al. (2020) 'Telemedicine and the COVID-19 Pandemic, Lessons For The Future', Telemedicine and $e$ Health, 26(5), pp. 571-573.

Beyrer, C. et al. (2015) 'The Vancouver Consensus: Antiretroviral Medicines, Medical Evidence, And Political Will', The Lancet. Lancet Publishing Group, pp. 505-507.

Bhaskar, S. et al. (2020) 'Designing Futuristic Telemedicine Using Artificial Intelligence and Robotics in the COVID-19 Era', Frontiers in Public Health, 8(November), pp. 1-7.

Bokolo Anthony Jnr (2020) 'Use of Telemedicine and Virtual Care for Remote Treatment in Response to COVID-19 Pandemic', Journal of Medical Systems, 44(7), pp. 1-9.

Bragazzi, N. L. et al. (2020) 'The Role of Hospital and Community Pharmacists in the Management of COVID-19: Towards an Expanded Definition of the Roles, Responsibilities, and Duties of the Pharmacist', Pharmacy, 8(3), p. 140.

Calton, B., Abedini, N. and Fratkin, M. (2020) 'Telemedicine in the Time of Coronavirus', Journal of Pain and Symptom Management, 60(1), pp. e12e14.

Craig, J. and Patterson, V. (2005) 'Introduction To The Practice Of Telemedicine', Journal of Telemedicine and Telecare, 11(1), pp. 3-9.

Dharma, A. A. G. S. S. (2020) 'Pengaturan Pelayanan Kesehatan yang Dilakukan oleh Dokter Melalui Telemedicine', Jurnal Magister Hukum Udayana, 9(3), pp. 621-631.

Djoyonegoro, N. (2020) Perang Global Melawan Corona: Perspektif Intelijen. Bogor: Yayasan Insan Waskita Nusantara.

Elliott, T. and Yopes, M. C. (2019) 'Directto-Consumer Telemedicine', Journal of 
Allergy and Clinical Immunology: In Practice, 7(8), pp. 2546-2552.

Freeman, R. E. (1984) Strategic management: A stakeholder approach, Strategic Management: A Stakeholder Approach. London: Pitman Publishing Ins.

Gan, W. H., Lim, J. W. and Koh, D. (2020) 'Preventing Intra-hospital Infection and Transmission of Coronavirus Disease 2019 in Health-care Workers', Safety and Health at Work, 11(2), pp. 241243.

Google, Temasek and Bain \& Company (2020) e-Conomy SEA 2020 Report : At Full Velocity, Resilient and Racing Ahead. Massachusetts. Available at: https://www.bain.com/insights/economy-sea-2020/.

Gostin, L. O. and Wiley, L. F. (2020) 'Governmental Public Health Powers during the COVID-19 Pandemic: Stayat-home Orders, Business Closures, and Travel Restrictions', JAMA - Journal of the American Medical Association, 323(21), pp. 2137-2138.

Grigsby, J. and Sanders, J. H. (1998) 'Telemedicine: Where it is and where it's going', Annals of Internal Medicine. American College of Physicians, pp. 123-127.

Hollander, J. E. and Carr, B. G. (2020) 'Virtually Perfect? Telemedicine for Covid-19', New England Journal of Medicine, 382(18), pp. 1679-1681.

Jian, D. (2020) Studies on Hospital Management Transformation. Singapore: World Scientific Publishing Co. Pte. Ltd, number 11589.

Kementerian Kesehatan Republik Indonesia (2010) 'Permenkes No 411 Tahun 2010 : Laboratorium Klinik.'

Kementerian Kesehatan Republik Indonesia (2017) 'Permenkes No 46 Tahun 2017 : Strategi E-Kesehatan Nasional.'

Kementerian Kesehatan Republik Indonesia (2018) 'Permenkes No 4 Tahun 2018 : Kewajiban Rumah Sakit dan Kewajiban Pasien'

Konsil Kedokteran Indonesia (2020) 'PKKI
No.74/2020: Kewenangan Klinis dan Praktik Kedokteran Melalui Telemedicine Pada Masa Pandemi COVID-19 di Indonesia'.

Kuntardjo, C. (2020) 'Dimensions of Ethics and Telemedicine in Indonesia: Enough of Permenkes Number 20 Year 2019 As a Frame of Telemedicine Practices in Indonesia?', Soepra, 6(1), pp. 1-14.

da Luz, P. L. (2019) 'Telemedicine and the Doctor/Patient Relationship', Arquivos Brasileiros de Cardiologia. pp. 100102.

Mahajan, V., Singh, T. and Azad, C. (2020) 'Using Telemedicine During the COVID-19 Pandemic', Indian Pediatrics, 57(7), pp. 658-661.

Mitchell, R. K., Agle, B. R. and Wood, D. J. (1997) 'Toward A Theory Of Stakeholder Identification and Salience: Defining the Principle of Who and What Really Counts', Academy of Management Review, 22(4), pp. 853886.

Omboni, S. (2020) 'Telemedicine during the COVID-19 in Italy: A Missed Opportunity?', Telemedicine and $e$ Health, 26(8), pp. 973-975.

Pacis, D. M. M., Subido, E. D. C. and Bugtai, N. T. (2018) 'Trends In Telemedicine Utilizing Artificial Intelligence', AIP Conference Proceedings, $1933 . \quad$ doi: 10.1063/1.5023979.

PB IDI (2020) Pedoman Standar Perlindungan Dokter di Era Covid-19. Jakarta: PB Ikatan Dokter Indonesia (PB IDI).

Pinzon, R., Paramitha, D. and Wijaya, V. O. (2020) 'Acceleration Of Telemedicine Use For Chronic Neurological Disease Patients During Covid-19 Pandemic In Yogyakarta, Indonesia: A Case Series Study', Kesmas, 15(2), pp. 28-31.

PORI (2020) Kebijakan Pori Teleradioterapi di Masa Pandemik Covid-19. Jakarta: Perhimpunan Dokter Spesialis Onkologi Radiasi Indonesia.

Presiden Republik Indonesia (2007) 'Perpres No. 86 Tahun 2007 : Badan 
Pusat Statistik".

Presiden Republik Indonesia (2015) 'Perpres No. 54 Tahun 2015 : Kementerian Komunikasi dan Informatika".

Presiden Republik Indonesia (2015) 'Perpres No. 35 Tahun 2015 : Kementerian Kesehatan".

Presiden Republik Indonesia (2020) 'Perpres No. 82 Tahun 2020 : Komite Penanganan Corona Virus Disease 2019 (Covid-19) dan Pemulihan Ekonomi Nasional".

Presiden Republik Indonesia (2015) 'Perpres No. 44 Tahun 2015 : Kementerian Hukum Dan Hak Asasi Manusia".

Presiden Republik Indonesia (2015) 'Perpres No. 65 Tahun 2015 : Kementerian Perencanaan Pembangunan Nasional".

Presiden Republik Indonesia (2015) 'Perpres No. 13 Tahun 2015 : Kementerian Perencanaan Pembangunan Nasional".

Presiden Republik Indonesia (2015) 'Perpres No. 12 Tahun 2015 : Kementerian Desa, Pembangunan Daerah Tertinggal, Dan Transmigrasi”.

Presiden Republik Indonesia (2015) 'Perpres No. 49 Tahun 2015 : Lembaga Penerbangan Dan Antariksa Nasional".

Presiden Republik Indonesia (2017) 'Perpres No. 53 Tahun 2017 : Badan Siber Dan Sandi Negara".

Ran, L. et al. (2020) "Risk Factors of Healthcare Workers With Coronavirus Disease 2019: A Retrospective Cohort Study in a Designated Hospital of Wuhan in China', Clinical Infectious Diseases, 71(16), pp. 2218-2221.

Royce, T. J., Sanoff, H. K. and Rewari, A. (2020) 'Telemedicine for Cancer Care in the Time of COVID-19', JAMA Oncology. American Medical Association, pp. 1698-1699.

Santosa (2020) 'Analisis Dampak Pandemi Covid 19 Terhadap Perekonomian Lokal dari Sudut Pandang Jenis Pekerjaan dan Pendapatan Terhadap
Tingkat Daya Beli Masyarakat di Jawa Tengah', PREPOTIF : Jurnal Kesehatan Masyarakat, 4(2), pp. 253267.

Sianipar, B. H. (2015) 'Kebijakan Pengembangan Tele-Medisin di Indonesia', Kajian Kebijakan dan Hukum Kedirgantaraan, 1(1), pp. 4262.

Sohrabi, C. et al. (2020) 'World Health Organization Declares Global Emergency: A Review Of The 2019 Novel Coronavirus (COVID-19)', International Journal of Surgery. Elsevier Ltd, pp. 71-76.

Stein, R. A. (2015) 'Political Will And International Collaborative Frameworks In Infectious Diseases', International Journal of Clinical Practice, 69(1), pp. 41-48.

Usman, U. (2016) 'Mencari Aktor Utama Dalam Proses Pembuatan Kebijakan Agama (Tinjauan Buku)', Jurnal Masyarakat dan Budaya, 18(1), pp. 147-155.

Utoyo, B. (2017) 'Analisis Kebijakan Prinsip Governance dan Aktor Melalui Analytical Hierarchy Process (AHP) dalam Perencanaan Kota', Jurnal Spirit Publik, 12(1), pp. 45-56.

Waller, M. and Stotler, C. (2018) 'Telemedicine: a Primer', Current Allergy and Asthma Reports, 18(10), pp. $1-9$.

Wiweko, B., Zesario, A. and Agung, P. G. (2016) 'Overview The Development Of Tele Health And Mobile Health Application In Indonesia', ICACSIS, pp. 9-14.

World Health Organization (2010) TELEMEDICINE : Opportunities and developments in Member States. Switzerland: WHO Press. 